\title{
HALYNA CHOMENKO
}

Charkowski Narodowy Uniwersytet Pedagogiczny im. H. S. Skoworody, Ukraina

\section{Проблематичність проща(е)ння: випадок Миколи Хвильового}

У просторі пост(пост)сучасної гуманітаристики, яка підкреслює свою причетність до ситуації krinein, пам'ять постійно зазнає критичного перегляду, породжуючи жест напруженого й суперечливого прощання/прощення. За цих обставин саме традиційне прощзай/прости в події смерті (,Бог тебя проcmum - ответ просящему прощенья: т. е. не мне тебя прощать, я такой же грешник"1) потрапляє в реторту справді революційного мислення, зразком якого є філософія деконструкції у версії Жака Дерріда. Радикальний деконструктивний переворот Дерріда співвідносний із думкою, що „сам Бог не может взять на себе прощения”, бо винуватість, „одновременно божественная и дьявольськая”, „,тарше его”2. Апорійність і парадоксальність, які стали визначальними характеристиками деконструкції, зумовили появу думки, що прощенню підлягає тільки те, що простити неможливо:

Ми повинні неодноразово піддати випробовуванню цю апорію формально порожню й суху, але невмолимо вимогливу: прощення, якщо воно $є$, повинно й може пробачити лише те, що не пробачається, те, що не спокутується — та відповідно зробити неможливе. Простити те, що може бути прощеним, вибаченим, перепрошеним, те, що завжди може бути пробаченим, це не $є$ прощенням. Проте сила аргументу, який не піддається сумніву, в частині, що має назву „Пробачити?” — це те, що своєрідність Шоа в розмірах iii неспокутуваності; і те, що для неспокутуваності, немає можливого прощення, ні для прощення, що має якийсь сенс, надає сенсу. Ця аксіома загальна для традиції, зрештою, і для Янкелевича, але ми можемо піддати iї сумніву, зокрема в тому, що прощення по-

1 В. Даль, Толковый словарь живого великорусского языка: Современное написание. В четырёх томах, т. 3, Москва 2003, с. 857.

2 Ж. Деррида, О почтовой открытке от Сократа до Фрейда и не только, пер. Г. Михалкович, Минск 1999, с. 279. 
винно мати якийсь сенс і що цей сенс має бути визначений через спасіння, примирення, спокутування, нове посвячення, я б навіть сказав, що це неможливо 3 .

Французьке pardon означає як дарування, прощення, вибачення, так і покаяння, спокутування, себто те, що розрізняється не тільки в просторі секулярного/сакрального, але й у просторі диссемінації множини відтінків кожного із цих значень, часом виявляючи їх апорійність:

Вибачте! Вибачте, що неприпустимо зайняв стільки вашого часу. Дякую. Коли ми говоримо „дякую”, чи ми дійсно говоримо „дякую”, я дякую тобі за те, що ти мені даєш та я вдячно визнаю? Чи, „даючи” я прошу в тебе пощади, я прошу тебе не бути „нещадним”, я прошу в тебе прощення за те, що ти мені даєш, я дякую тобі за милість, за прощення, яке я прошу вас знову дати мені, і т. д.? по суті, ви ніколи не дізнаєтесь, що я вам кажу, коли я вам говорю, на завершення, так само, як і на початку, вибачте, дякую. Спочатку було слово „прости”, „дякую”" .

Українська мова могла б бути добрим матеріалом для експериментів за приписами деконструкції, про що свідчать синоніми пробачати/прощати та пароніми прощати/прощатися („Пробачати чию-небудь провину, виявляти поблажливість до когось”/,...говорити слова прощання”; „Останній раз дивитися на покійника, віддавати йому останню шану перед похованням”; ,Залишати надовго або назавжди що-небудь, розставатися з чимось"5). Симетрія може бути подвоєна під дією нової (а)симетрії пробачити/вибачити в значенні дарувати, себто віддавати даремно, що є синонімом як без відплати, так і марно. Лише Дерріда на підставі виключення дару зі сфери економії активізує механізм différence прощення і пробачення: прощення аналогічне трансформації пам'яті в „абсолютне забуття — забуття, яке відпускає гріхи, яке повністю прощає, безкінечно більше, аніж пробачення, вибачення або виправдання" .

Тож поряд із констатацією невизначеності сенсу прощання/прощення деконструкція вимагає усвідомлення його проблематичності. Не в значенні необхідності розміститися перед проблемою („в смысле того, что в точности имеешь перед собой в качестве задачи" "). Проблематичність дістає новий відтінок - невпевненості (те, що для мене проблематичне/я не впевнений у цьому ${ }^{8}$ ). Проблематичне забороняє прийняття рішення й ідентифікацію того, що зачинене у своєму панцирі на зразок військового обладунку привиду батька Гамлета (від problema - щит) $)^{9}$. Тут проблематичність визначення,

3 J. Derrida, Pardonner. Limpardonnable et l'imprescriptible, Paris 2012, c. 28-29 - пер. Т. Черкашина.

${ }^{4}$ Ibidem, c. 72.

5 Великий тлумачний словник сучасної української мови, ред. В. Бусел, Київ 2003, с. 999.

6 Ж. Дерріда, Дарувати час, пер. М. Ющенко, Літопис, Львів 2008, с. 25.

7 Ж. Деррида, Вокруг Вавилонских бамен, пер. В. Лапицкий, Санкт-Петербург 2002, с. 32.

8 О Даре: Дискуссия между Жаком Деррида и Жаном-Люком Маримоном, пер. В. Рокитянского, ред. А. Ямпольской, „Логос” 2011, № 3, с. 148.

9 Ж. Дерріда, Привиди Маркса, пер. І. Донченко, ред. О. Мамалуй, М. Руденко, Харків 2000, c. 52.

Slavica Wratislaviensia 173, 2020

(C) for this edition by CNS 
дефініції співвідноситься із афінацією — процесом, що виводить у безкінечність й бездонність.

Філософія „деконструктора до деконструкції”10 Фрідріха Ніцше, яка структурувала чи не всі національні модернізми, висувала дар прощати(ся) в простір життя особливої людини. Критерієм ії вирізнення є володіння непростим мистецтвом розрізнення того, що безумовно варте пам'яті, i того, що варто забути. Особлива (шляхетна) людина увиразнювалася своєю здатністю на блаженний вияв забування, 3 яким відбувалося прощання з тягарем минулого й відкривалися перспективи майбутнього - парадоксальний жест, у якому із забуванням/прощанням зникала можливість прощення, яке можливе тільки за умови існування в пам'яті. Парадокс Ніцше співвідноситься із людиною, яка в умовах смерті Бога висунула мету створити ілюзію його присутності, заповнивши порожнечу завдяки тим якостям, які ставили б іï на один рівень із убитим Богом. За Ніцше, це не стільки здатність до милосердя, скільки вміння безвинного взяти на себе провину або інших, або надуману іншими провину:

Кто достаточно богат, для того является даже счастьем нести на себе несправедливость. Бог, который сошел бы на землю, не стал бы ничего другого делать, кроме несправедливости, - взять на себя не наказание, а вину, — только это было бы божественно (курсив Ніцше - Г. Х.) $)^{11}$.

Складність ситуації прощання/прощення винного невинного набуває абсолютного характеру через свою загадковість та утаємниченість, через відсутність сцени проща(е)ння. На зразок того, з чим стикаємося у випадку Миколи Хвильового - людини, яка стала вищою за свою епоху показного каяття й заміщення метаної параноєю.

Проблематичність проща(е)ння задана тут унікальними речами, які позиціонують деконструктивне пере-життя. Це таємничі листи ${ }^{12}$, залишені самовбивцею на секретері: до доньки/пасербиці Любові Григорівни Уманцевої (17.06.1914-28.08.1998), нерідної доньки, яка жила разом з ним упродовж 12 років і виявилася ріднішою за рідну, та до друзів - проблематичної категорії людей у світі не тільки без Бога, але й без Друзів (у поезії Час (1926), яку Володимир Сосюра адресував М. Хвильовому, є рядки: „Це тобі моя піс-

10 Н. Автономова, Философский язык Жака Деррида, Москва 2011, с. 64.

11 Ф. Ницше, Ecсе hoто. Как становятся сами собой, пер. Ю. Антоновский, [в:] idem, Сочинения. В двух томах, т. 2, Москва 1990, с. 703.

12 Це утаємничені тексти, тексти, приховані в нинішньому ГДА СБУ, які стають об'єктом роз-/ при-гадування через 55 років від часу їх написання. На підставі листування Любові Уманцевої та Світлани Клімової (далі цитоване мовою оригіналу), яке зберігається у фондах Харківського літературного музею, можна судити, що вперше вони були оприлюднені академіком Федором Овчаренком на урочистостях у Києві 13 грудня 1988 року з нагоди 95-річчя Хвильового. Фіксація дат важлива не так з точки зору історії, як екзистенції: хоча в середовищі сучасників самовбивці велася мова про його передсмертні листи, які спіткала загадкова доля чи то з волі/вини генерального прокурора в спецсправах ГПУ УРСР Григорія Желєзногорського, чи то завдяки невдалим/неповним копіям, що їх зробив Юрій Смолич. 
ня, Миколо, / в цей скажений, розтерзаний час [...] Знаєм ми, ще так довго чекати, / ми не дружні, не щирі, о жах!..”13).

Здається, уже їх роздвоєний зміст, який випливає з розрізнення адресатів, зумовлює апеляцію до приписів деконструкції: передсмертне послання доньці/пасербиці містить просьбу про прощення складної для розуміння вини батька, натомість прощання з друзями супроводить не тільки відсутність такого прохання, але й інверсивне переведення адресатів у статус боржників доньки/пасербиці та непряму підозру влади в аномії. Пізніше Уманцева діалектично об'єднає обидва листи, підпорядковуючи їх моногенеалогію власному міфу про єдину доньку (iї дискурс проймає сумнів щодо рідної доньки Хвильового). Однак не можна не помітити, що для Хвильового важливим $\epsilon$ не тільки їх кваліфікація у вимірі подвійної генеалогії différence, а використання „дружнього” послання з метою самоідентифікації у стилі Ніцше у спосіб перебирання на себе відповідальності за інших попри цілковите нерозуміння ні їхньої, ні своєї винуватості. Жест особливої людини, який можна тут розгледіти, — це ні прохання, ні не прохання, а щось вкрай невловне для референції, від чого сама необхідність прохання про прощення стає проблематичною.

Подія прохання про прощення, як відомо, $є$ важливою парадоксальною структурою в деконструкції. Апелюючи до Володимира Янкелевича, який уважав прохання обов'язковим і необхідним компонентом історії прощення, Дерріда писав:

Для Янкелевича, як і для більшості традицій (тих, у яких ми дійсно маємо ідею прощення, але ідею прощення, яка спадково містить силу імплозії [вибуху, спрямованого всередину], у якій ми не припиняємо реєструвати дефлаграцію [вибуху із швидким згоранням], спадок, який суперечить сам собі, виходить із самого себе, спалахує, я б сказав ще - „деконструює” сам себе), цілком очевидно, що прощення може бути надане лише в тому випадку, коли винуватець сам себе умертвить, висповідається, покається, визнає свою провину, просячи прощення, якщо таким чином він спокутує вину, і відповідно ідентифікує себе, з метою спокутування та нового посвячення, з тим, у кого він просить прощення ${ }^{14}$.

У випадку Хвильового прохання простити співвідносне не тільки з незбагненним відчуттям (не)провини й готовністю іiї спокутувати, але з потребою виокремити лише тих, хто спроможний чи здатний простити, хто вартий почути просьбу про прощення: для Хвильового, захопленого Ніцше, любов до розрізнень зумовила установку на самовідрізнення від інших, трансформуючись в апеляцію лише до окремих, хто зміг би відчути апорійніть послань.

Першою рисою „свого” адресата Хвильовий уважав його дар відчувати „запах слова”"15. У листі до доньки він аналогічний нетрадиційному „винюху-

13 Дорогий Аркадію. Листування та архіварія літературного середовища України 1922-1945 pp., упор. Л. Демська-Будзуляк, Львів 2001, с. 57.

14 J. Derrida, Pardonner..., c. 24.

15 М. Хвильовий, Арабески, [в:] idem, Твори. У двох томах, т. 1, упоряд. М. Жулинський, П. Майдаченко, Київ 1990, с. 309.

Slavica Wratislaviensia 173, 2020

(C) for this edition by CNS 
ванню” простих слів пробач/прощзай, які складають або рамку послання, або точки перегуку, позначаючи необхідність їх відповідальності одного перед іншим: „...пробач мене, моя голубонько сизокрила, за все. [...] Прощай, мій золотий Любисток" 16 . Реляція двох слів, що мають протилежну семантику щодо мнемонічного наповнення - унікальний привід для деконструктивного мислення, зосередженого на протиріччях подвійного припису: пробачити стосується справ минущих, проминальних, повсякденних; прощзати - зі світу небуденного; окрім того, пробачити = забути, усунути 3-перед очей пам'яті; прощай = не забувай, пам'ятай. Адресатка ігнорує це вербальне розмежування, інтуїтивно абсолютизуючи лише „прощай”, реанімоване під тягарем зустрічі зі смертю батька та його передсмертним „прощай”, за яким зникає гра сенсів. Поранена цим словом, вона виявляє повну безпорадність: „Чому Ви написали „прощаюсь с Вами”? Було боляче таке читати”17.

Гостра реакція на слово прощай - наслідок і вияв піднесення до другого ступеня перечитування листів Хвильового в часописі „Прапор” за 1989 рік: „Перше, що я прочитала, были 2 листи від 13 травня 33. На мене звалилася така сила переживань, що мені здається, що от уже я не витримаю"18. Уманцева парафразовує полісемантичний припис відчувати ,запах слова” = підкорятися його силі. Ї̈̈ зізнання-імплікат про зачарованість прощальним словом батька аналогічне експлікації магії слова прощзай у шанованого Хвильовим Олександра Дюма (батька). Таємниця прощай у Дюма постає 3 дивовижної інверсії прощання Д'Артаньяна в останній книзі трилогії „Віконт де Бражелон, або Десять років потому” („Le Vicomte de Bragelonne ou Dix ans plus tard", 1847-1850). Помираючи, Д’Артаньян каже слова, які ніхто, крім нього, уже не здатен буде зрозуміти: Атос, Портос, до побачення (au revoir); Араміс, прощай назавжди (a jamis adieu). У мить смерті він „каже до побачення мертвим друзям і прощзай назавжди другові, який лишається живим, другові, душу якого вже прибрав Господь, другові, який приречений жити вічно, знаючи, що жоден із друзів ніколи не промовить йому слова прощання" (курсив Рудинеско. - Г. Х.. ${ }^{19}$.

У Дерріда слово-парадокс adieu дістало онтологічну оптику: воно позначає і наближення до Бога (до Dieu), і віддалення чи відштовхування від нього, прощання з ним чи з канонічними розуміннями Бога. У роботі Дар cмepmi (Donner la mort, 1992) слово adieu може означати три речі: 1) привітання чи благословення, яке зазвичай вимовляють під час зустрічі як констатація того, що розмова відбувається, навіть коли співрозмовники одне одно-

16 М. Хвильовий, Передсмертні послання до пасербииі Любові Уманцевої $і$ до друзівписьменників, [в:] idem, Твори. У двох томах, т. 2, упоряд. М. Жулинський, П. Майдаченко, Київ 1990, с. 888.

17 Лист Л. Уманцевої від 16.05.90. Фонди Харківського літературного музею. Вст. № 28737. РП 3929/1.

18 Лист Л. Уманиевої від 7.ІІІ.89. Фонди Харківського літературного музею. Вст. № 28727. РП 3919/2.

19 Е. Рудинеско, Філософи в обіймах бурі, пер. О. Юдін, Київ 2007, с. 200. 
му ще нічого не сказали, і того, що вони бачать одне одного; 2) напучування або привітання в момент розлуки - можливо, назавжди, у момент смерті; 3) нарешті, A-dieu як відповідь Богові або перед Богом, з Богом, заради Бога, за-Бога ${ }^{20}$. A-dieu (до Dieu) може означати віднесення до Бога або стояння перед Богом; але це може мати на увазі і ставлення до іншої людини, що відкривається (або ж утілюється в слова) перед Богом, до чого додається ще одна важлива можливість: „A-Dieu — это идея бесконечного в конечном”21. Диссемінація adieu дозволяє підозру в нетривіальності прощзай Уманцевої, а відтак, можливість його аналізу за приписом окільного шляху.

Хоча прочитання послань про проща(е)ння передбачає нескінченний ланцюг розклинювальних спостережень, варто розпочати 3 їх віднесення в забуття. Ситуацію можна було б пояснити законом традиційного платонівського ритму зникнення/поява. Однак тривале усунення із реальності корелят того величного небуття, яке зберігає все. Парадокс: перша умова знищення кореспонденції — це вдавання, що збереглися окремі фрагменти, які варті того, щоб потрапити в будь-які руки. Навпаки, повне забуття, ситуація, коли „мы лучше забудем все [...], позволит нам начать все сначала" 22 . Єдиний шанс повернутися до життя - бути повністю викресленим із пам’яті, чому відповідає метафора голокосту пам’яті Дерріда: попіл всеспалення в мнемонічному просторі породжує потужний вогонь пам'яті.

Справді, для адресатки Уманцевої виявлення прощальних листів батька було вражаючою несподіванкою, яка викликала бурхливу реакцію: „А на вечорі в Києві мене вбили, просто вбили, коли почали читати його передсмертні листи"23. Неможливі переживання жінки структурують простір, доступ у який стає можливим завдяки досвіду деконструкції з його множиною складних перетинів. Така симетрія повернення/дарування спадку як дарування смерті могла б бути пояснена в межах ейфорійно-поетичного формульного мислення, якби не один нюанс: ця подія — pharmacon дару з асиметрією життя/смерті, радості/болю, але водночас даром вона не є: „дар зникає, як тільки інший його отримує й навіть якщо він відмовляється від дару, який він сприйняв або визнав за дар. Як тільки він надає дару значення дару, він втрачає його, дар перестає існувати"24. Однак до сфери дару він потрапляє на підставі несподіваності, виходу за межі злагодженого, звичного: „Ви зробили мені гарний струс!”25.

20 Ж. Деррида, Дар смерти, пер. Ю. Азаровой, „Вісник Харківського національного університету ім. В. Н. Каразіна. Серія: теорія культури і філософія науки” 2, 2002, с. 13.

${ }^{21}$ Н. Автономова, Философский язык..., с. 257.

22 Ж. Деррида, О почтовой..., с. 279.

23 Л. Уманцева, ,, Він у крові мав: творити, а змушували вигинатися...”. Бесіда з дочкою М. Хвильового О. Мурзіної, „Ленінська зміна” 16.09.1989, с. 6.

24 ж. Дерріда, Дарувати час..., с. 23.

25 Лист Л. Уманцевої без дати: в Харкові 02.12.93. Фонди Харківського літературного музею. Вст. № 28788. РП 3959/1. 
Це більше аніж шок, що його могли б кваліфікувати як клінічний синдром чи психоаналітичну роботу горя, ядром якої є не скорбота, а патологічне (інцестуальне) відчуття посилення лібідо, лібідонозний прорив, що $\epsilon$ формою „транзиторного неврозу” Винникота ${ }^{26}$, можливість і ймовірність якого запідозрена в окремих інтерпретаціях Хвильового. Тільки ж у випадку iз переживанням смерті батька наука пропонує цілий ансамбль, закономірний для психічної структури доньки в такому випадку: Над-я класичного психоаналізу, Закон і Символіка в структуральному психоаналізі Жака Лакана. А Дерріда ототожнює поворот до батька (мертвого) із поворотом до Логосу/голосу. Саме так в Уманцевої: для неї читати останні листи батька „це як розмова 3 ним” 27 . Більша довіра до голосу, аніж до письма дістає в неї виразну батьківську сцену: „Може при нашій зустрічі я розповім Вам як Григорович бушував 12 травня 1933 р. в страшній тузі, намагався зупинити те страшне, що нависло над Україною" 28 . Зрештою, і писання листів стає необхідною операцією оживлення множини фрагментів пам'яті з метою увиразнення батьківської логіки хіазму Любочки/Любистка. На зразок:

Все писатели дома „Слово” знали только одну дочь Хвылевого - Любочку — Любистка, постоянного его супутника - в театры, редакции, организации и др. Уже только из одного письма можно понять кем для него была и кого он ніжно любил - золотого Любистка ${ }^{29}$.

Деконструкція прощення/прощання у випадку Хвильового могла б бути більш результативною завдяки відхиленню до юнгіанського психоаналізу: Уманцева $є$ просто-таки зразком puella aeterna (вічної дівчинки) ${ }^{30}$. Для такого визначення досить було б скористатися ії повторюваною самохарактеристикою сеньйори як інфанти: іiі листи — територія послідовного нагадування про „вічну дитину — любистка”, яка „змалечку була балована та всіми кохана [...]"31; завдяки підкресленню такою донькою гораціанства батька той постає як puer aetenus (вічний юнак). Здавалося б, на користь результативності методологічного повороту свідчать і додаткові матеріали: фото доньки й матері 1920 року, новела Kim у чоботях (1922), протокол допиту Юлії Уманцевої 13 травня 1933 року тощо. Вони є матричними для пуели:

26 М. Торок, Болезнь траура и фантазм чудесного трупа, пер. А. Тхостова, К. Костаревой, [в:] Франиузская психоаналитическая школа. Сборник статей, ред. А. Жибо, А. Россохин, Санкт-Петербург 2005, с. 319.

27 Лист Л. Уманиевої від 28.05.89. Фонди Харківського літературного музею. Вст. № 28794. РП 3965/1.

28 Лист Л. Уманцевої без дати. Фонди Харківського літературного музею. Вст. № 304. РП4895/1-2.

29 Лист Л. Уманиевої від 03.05.94. Фонди Харківського літературного музею. Вст. № 28786. РП 3958/2.

30 Л. Ш Леонард, Эмоциональная женская травма: Исиеление детской травмы, полученной дочерью в отношениях с отчом, пер. В. Мершавки, Москва 2013, с. 35.

31 Лист Л. Уманцевої від 21.03.91. Фонди Харківського літературного музею. Вст. № 28741. РП 3933/1. 
мати з розщепленою фемінністю, витончена й приваблива, так само „вічна дівчинка”, демонструє себе як незалежна й войовнича „амазонка в панцирі”, неспроможна на насолоду від сексуального життя із чоловіком і віддалена від нього; батько, фрустрований таким шлюбом, надзвичайно сильно любить доньку, можливо, навіть відчуває до неї позасвідомий сексуальний потяг, що породжує закономірне відчуття провини ${ }^{32}$.

Здавалося б, синдром „вічної юності” у випадку проща(е)ння Хвильового та Любистка стає виразнішим, коли зважити, що обидва архетипні патерни — пуела та пуер — перш за все відзначаються особливою вразливістю та ідентифікацією із жертвою, де винуватість займає суперечливе окреслення: вона або повністю елімінується, або ж повністю переноситься на себе; тут можлива або відчайдушна винуватість, або радикальна невинуватість ${ }^{33}$. У чому може бачити свою вину Любисток? Найперше в тому, що остання просьба батька вранці 13 травня не була почутою:

Того дня я пішла на заняття, у музичному училищі вже вчилася. Микола Григорович мені сказав: „Голубонько, не ходи. Сьогодні можна не ходити”. Але я вважала, що заняття пропускати не можна. Пішла. А коли поверталася, зайшла до будинку... ${ }^{34}$

У чому міг убачати себе винним Хвильовий? Відповідь може бути парадоксальною: „...вот она вина — чувствовать себя невиновным” ${ }^{35}$. Вона складніша, аніж вина за раптове зруйнування захисного кола для доньки, що стає для неї катастрофою. Хвильовий пише в ситуації, яка знаходиться за межами його розуміння, в реальності, яку сприймав із простодушною прямотою, що́ виявилося непоправною помилкою. Однак світ як сцена зради й відступництва (чого варта сентенція часу смерті ВАПЛІТЕ: „,..Хвильовий тягне до табору українського войовничого фашизму, а ви туди не хочете йти, то відрікайтеся від нього, як ви вже від нього ж колись відреклись" (курсив Скрипника. - Г. Х. $)^{36}$; чи свідчення заарештованого Михайла Ялового: „Але з іншими партійцями, звісно, таких розмов, як із Хвильовим, я не мав"37) не викликає в нього бажання дистанціюватися, а формує напружене питання в стилі кенозису борхесівської єретичної христології. Вина невинного вина людини 3 мерехтінням пам'яті про нетотожність атрибутів іmpeccabilitas та humanitas, непогрішності й олюднення, для якої ця нетотожність

32 Л. Ш. Леонард, Эмочиональная, с. 54.

33 Ibidem, c. 40.

34 Л. Уманцева, „Він у крові мав”,.., с. 6.

35 Ж. Деррида, О почтовой..., с. 295.

36 М. Скрипник, Нама літературна дійсність (Із прикінцевого слова на диспуті в Харкові в Будинку літератури ім.. Блакитного 21 лютого 1928 р.), [в:] Шляхи розвитку української пролетарської літератури. Літературна дискусія (1925-1928). Збірник матеріялів. Статті, літературні маніфести, постанови партії в справах художньої літератури, упоряд. С. Федчишин, ред. В. Коряка, Харків 1928, с. 232.

37 Архів Розстріляного Відродження: матеріали архівно-слідчих справ украӥнських письменників 1920-1930-х років, упоряд. О. й Л. Ушкалових, Київ 2010, с. 41. 
ускладнюється до апорійний нi/нi//maк/maк. У ситуації з листом до доньки апорія переживання вини співвідносна не з очікуваним порушення обіцянки чи клятви про відмову від самовбивства. Навпаки, адресатка має відчути атопічність такого жесту. I те, що прохання про прощення не передбачає автоматизму реакції прощання, адресант-самовбивця увиразнює аргументом спалення тексту як безповоротним учинком, як сигналом про неможливість жити за умов неможливості писати. I, найголовніше, вбачає в цім не прояв покори обставинам, а вибух сили і власний тріумф: „...3нищив - значить знайшов у собі силу волі зробити те, що я сьогодні роблю"з8. Тут сила волі дістає перетин із чіткістю мислі: Хвильовий просить пробачення, зважаючи на симетрію пробачення й розуміння, прояснюючи/пояснюючи вчинок ,„розумними міркуваннями”, усвідомлюючи необхідність думки, що „приймати рішення необхідно з розумом" 39 . Однак його прохання - простір осциляції між розумом і нерозумністю, простір „радості бунту проти логіки” та життя як „безумної подорожі"40, де можлива неможлива ірраціональна раціональність Я, що, у просторі метафоричного мислення Зигмунда Фройда, як не $\epsilon$ господарем у власному домі, так і зваблює волею до невпійманості й непізнаності. Це безумство прориву депресії, аналогічне випаду проти розумного глузду, однак це єдина можливість руху від смерті до життя, відмови від мертвого заради живого. Це тріумф волі до життя в амбіваленції Еросу й Танатосу, волі до життя й волі до смерті як ірраціонального ніколи не знищенного єства людини ${ }^{41}$. Це та філософія, яка поставила б під сумнів інтерпретацію руїн гомерівського Каміроса як випадку пароксизму, „колективного потьмарення ума”, вияву „універсального механізму дегуманізації,42.

Деконструкція дозволила б хіба вести мову про межовий статус Хвильового в листі до Любистка, про передсмертний лист як простір ніцшеанського танцю між вищою людиною (höherer Mensch) і надлюдиною (Übermensch), де перша робить останні рухи скорботи й жалю, а інша чинить «не по-людськи», „сжигает свой текст и стирает следы своих шагов"43. У цім простоpi - справжній тріумф роздвоєності. Тож і в самому жесті спалення - як демонстрація надлюдиною своєї байдужості до сенсу й наслідків скоєного, до його вписування в метафізику сенсу, так і демонстрація власної волі, власного бажання: те, що я так чиню, — не реакція на обставини, а вищий момент в акції самотворчості, за яким могли бути слова: «Це я сам так хотів. Я — не жерва. Я — творець». Роздвоєність доповнюється реалією дому, де

38 М. Хвильовий, Передсмертні..., с. 888.

39 Ж. Дерріда, Дарувати ..., с. 99.

40 М. Хвильовий, Арабески..., с. 318.

41 Е. Рудинеско, Навіщуо нам психоаналіз?, пер. С. Марічев, Київ 2008, с. 29-30.

42 О. Забужко, Замість передмови: пам'ятаючи про Камірос, [в:] еаdет, „I знов я влізаю в танк...”. Вибані тексти 2012-2016: Статті, есе, інтерв'ю, спогади, Київ 2016, с. 13.

43 Ж. Деррида, Концы человека, [в:] idem, Поля философии, пер. Д. Кралечкина, Москва 2012, c. 168. 
було скоєне самовбивство: у заданому контексті дім постає знаком розхитування пам'яті про гайдеггерівський дім буття як територію онтології сенсу або про перетворення відомої філософської метафори в метафору дому надлюдини, яка не потребує пригадування та зберігання сенсу буття, самовбивство якої асоціюється із потребою активного забування буттєвості людини.

Власне, уся історія проща(е)ння Любистка із Хвильовим сприймається атопічною й неможливою, що́ увиразнюють навіть щоденникові записи Івана Дніпровського про „тихе божевілля” будинку „Слово” після пострілу Хвильового ${ }^{44}$. Для доньки це не тільки неможливі переживання минулого й анамнестична робота над батьківським спадком у книзі 100 спогадів Любистка (підготовлена до сторіччя батька, у 1993 році, вона й досі не видана). Хоча, як про те свідчать листи, написання спогадів є тим звичайним завданням, яке відмежувало б жінку від інших сучасників Хвильового, іiі місію в продовженні справи батька. Не у сфері творчості: поезію Уманцевої не віднесеш до тих маленьких шедеврів, у яких Європа відкрила Хвильового; а ії критичні зауваження щодо Сентиментальної історії та авторських коментарів до вибраних творів 1930-х надзвичайно сумнівні. Пережиття батькового сенсу життя можна збагнути з уламку інтерв’ю з Любов’ю Григорівною:

У нас бібліотека була маленька, але гарна. I він привчав мене читати змалечку. Читав вірші - багато, безліч. А з великими книжками робив так: починав мені читати, а потім каже: далі сама давай. Так він мені прочитав Діккенса, а я далі сама, сама, і всього Діккенса прочитала. Бальзак, Рабле і наші письменники, звісно. I хто б це міг не захоплюватися літературою поруч з ним ${ }^{45}$

Тут маневр у стилі прощань Дерріда: далі - сама, далі йти одній. Він так само буде увиразнюватися: необхідність жити з відчуттям розриву з батьком дістане в листах доньки відповідник - експансію багатокрапки. Ці крапки - рана, уся полісемантика якої не може прикрити іiї можливу аналогію iз раною істини, яка сигналізує про втрату інстинкту самозбереження в прагненні істини, чим вирізнявся сам Хвильовий ${ }^{46}$. Для Уманцевої — це перш за все істина свого місця в житті батька. Справа навіть не в оперуванні нею особливими фактами, якими не володіє ніхто інший, які дозволяють поставити під сумнів свідчення інших або кваліфікувати їх у просторі замовчування чи викривлення правди. Справа в силі ії свідчень, які структуровані подією прощання з батьком. Вона ж - цілковита порожнеча, бо прощання не було:

Я була на похованні Блакитного. А на похованні Миколи Григоровича — ні, мертвим я його не бачила. [...]. Потім мені сказали, що батько застрелився. Я втратила мову, я не могла нічого говорити. Цього не можна переповісти. Потім мене відвезли до бабусі, і я його ніколи вже не побачила ${ }^{47}$.

44 І. Дніпровський, 3і щеоденника 1933-го року, „Український засів” 1994, № 1, с. 75.

45 Л. Уманцева, ,, Він у крові”..., с. 6.

46 Ж. Деррида, Дальще мне предстоит идти одному, пер. А. Меликян, https://www.gumer.info/bogoslov_buks [доступ: 9.01.2019].

47 Л. Уманцева, ,Він у крові”..., с. 6. 
13 травня мене не пустили (Я вертала із муз школи. На другому поверсі мене зустріли подружжя Эпіків (Віра та Грицько). Довго мовчали, ходили коло мене замучені люди і нарешті мені все „сказали”. Я відчула наче удар блискавиці. Була в такому стані немов Божевільна! Якась жінка відвезла мене в місто Золочів (там народилася моя мама Юлія Григоровна). Там хата бабусі, яблуневий цвіт, сіяє сонце, і я вже не плакала, а стогнала. Ніколи я не бачила Григоровича мертвим і повернулася в Харків вже коли ёго поховали ${ }^{48}$.

Удаючись до сучасного психоаналізу, тут можна спостерегти відродження депресивної позиції, пов'язаної із втратою Над-Я. Це той вид деструкції, яка має траурний колір: чорний або (i) білий: чорний - тяжка депресія, білий - стан виняткової порожнечі. Біла тривога/біле горе, взагалі увесь комплекс білого болю, „біла” серія, за Андре Грін, має відношення до того, що можна було б назвати клінікою пустоти або клінікою негативу, є наслідком ослаблення лібідинозної еротики. Це не тривога кастрації, що має кривавий колір. Це тривога витіснення. Як будь-яка форма деструкції, біла тривога $€$ раною, однак вона не має нічого спільного 3 кривавою мутиляцією ${ }^{49}$. Така рана могла стати джерелом слів: „P. S. Пишіть. Буду відповідати тільки не питайте про 13 травня 1933 р."50

Для Уманцевої писати - зовсім не те, що бачити. Не бачений нею мертвий батько є людиною, статус якої можна було б визначити з допомогою того тропу з філософської привидології Дерріда, який має назву „ефект шолома”: у військовому обладунку привида батька Гамлета шолом забезпечує не лише захист, але й засвідчує приналежність особи до владного стану за гребінцем 3 відзнакою над ним: „Мені, звичайно, важко як слід розповісти про його життя, але я можу засвідчити, що я більше не зустрічала такої чудової людини, яким був Микола Григорович" засвідчення, неможливість лінеарних чи лабіринтних історій, упорядкованих простою логікою / можливість слова, заснованого на довірі й інтуїції: така чудова людина по-іншому не могла, оскільки для чудових чудовий має не так естетичну чи етичну конотацію, як конотацію атопічності, неможливості, деструкцію матриці. Засвідчення того, що перебуває не тільки за свідка, у ролі свідка, але й за межами як усвідомленого, так і сприйнятого с-виду, фронтально, того, що відповідає косині й маргінальності, аналог непрощенного, непростимого.

48 Лист Л. Уманиевої без дати. Фонди Харківського літературного музею. НДФ № $3203 / 2$

49 А. Грин, Мертвая мать, пер. Е. Пашковой, [в:] Франиузская психоаналитическая школа. Сборник статей, ред. А. Жибо, А. Россохин, Санкт-Петербург 2005, с. 337.

50 Лист Л. Уманиевої з нечіткою датою 1989. Фонди Харківського літературного музею. Вст. 28745 РП3937/1. (Курсив мій. - Г. Х.)

51 Л. Уманцева, Учасникам урочистого засідання, присвяченого 100-річчю від дня народження Миколи Хвильового, „Український засів” 1994, № 1, с. 78 (Курсив мій. — Г. Х.). 
Натомість слово бачити стає визначальним в інтерв'ю Іраїди Дмитрівни Кривич (1920-2013), яку знають як рідну доньку Хвильового. Похорон єдина ситуація, де вона, за ії свідченням, бачила батька:

Людей було — страшне! Даня (сестра Катерини Гащенко. - Г. Х.) проштовхнулася зі мною крізь натовп - i ми побачили мою бабусю, матір Миколи Григоровича. Бабуся також побачила нас і попросила Даню, щоб вона провела нас поближче. Хвильовий лежав на білому катафалку, домовина - посередині. Бабуся весь час повторювала: „Це твій батько, це твій батько...”. А потім сказала: „Поцілуй його”. Я його запам’ятала, як він лежав. І поцілувала батька в щоку ${ }^{52}$.

Помилково (його немає на відомому фото) вибачений, зафіксований зоровою пам'яттю білий катафалк, може бути просто пробачений жінці поважного віку великодушним читачем . Але наступні спогади вимагають ревізії: „А навпроти стояла дівчинка, старша за мене - Люба Уманцева, прийомна донька Хвильового”; „Після того, що сталося, Уманцева виїхала в Росію. Люба написала мені один лист, я відповіла, а потім листування обірвалося"53. Фрагменти із ви(по)баченого - дивний мемуарний малюнок. За свідченням Уманцевої, родина, яку з невідомих причин не репресували, полишила будинок „Слово” лише в 1941 році під час евакуації; про існування ж І. Кривич вона дізналася тільки в 1993 році ${ }^{54}$.

Проща(е)ння Уманцевої можна визнати за реакцію на наголошену в передсмертних листах батька його волю до життя. Останні слова Хвильового сприймаються нею за логікою „я дарую собі смерть, хоча люблю життя”/ „я хотів би, щоб мені подарували життя, щоб ти зберегла мене живим, оскільки люблю життя". Цю логіку можна зрозуміти в межах пере-життя - важливого виміру в деконструкції, пов'язаного з різними рівнями скорботи. До його формування спонукає вже початкова скорбота, не кажучи про скорботу, пов'язану зі смертю, де пере-жити у значенні й ӥberleben (жити після смерті, як дитина після батьків), i fortleben, living on (продовжувати жити, жити далі), й erleben (уболівати) доповнюється значенням пере-мислити, включити в механізм ризикованого мислення. Закон гри l'abandon, le don, le pardon (невимушеність, дар, прощення) дозволяє жити слову чи виразу, породженим живою мислю, у спосіб потрійного привітання життя: одночасно дозволяючи імм жити самим, якими б вони не були, й оживляючи їх у поетичному сенсі, повертаючи їх із за(не)буття, й у спосіб неочікуваного оновлення ${ }^{55}$.

Можливо, тут імпліковане джерело відмови Уманцевої називати ім'я автора „страшної статті”, яка спричинила спробу самовбивства Юлії Уман-

52 Полювання на „Вальдинепа”. Розсекречений Микола Хвильовий, упоряд. Ю. Шаповал, передм. Ю. Шаповала, В. Панченка, Київ 2009, с. 246 .

53 Ibidem.

54 Лист Л. Уманцевої від 22.03.1994. Фонди Харківського літературного музею. Вст. № 28794. РП 3964.

55 Ж. Деррида, Э. Рудинеско, Искать свое наследие, пер. Н. Ефремов, http://www.uhimik. ru/studia-humanitatis-symposium-ejegodnij-mejdisciplinarnij-jurna/index3.html [доступ: 3.02.2019]. 
цевої: „Мама, яка витримала все... В неї тоді вже не вистачило сил, і вона зробила спробу накласти на себе руки" дія-пасус ${ }^{57}$ проти україністики Заходу з їі глоризацією Хвильового відкриває намір елімінувати його із життя у спосіб більш вражаючий, аніж постріл із браунінга. Лише справа в тім, що, відмовившись від можливостей кризового мислення в умовах постсталінської кризи, така критика гинула сама, утративши інстинктивне відчуття власної живої мислі через заміщення їі тривіальною волею до знищення чужої. Можливо, така критика - зразкова територія для навчання тепер прощанню/прощенню. У спосіб (iї) деконструкції. Обравши неможливий шлях абсолютизації неможливого.

Справді, філософська деконструкція Дерріда, що постала з необхідності перепрочитання минулого як survie й „,анамнезу незапам'ятного”, утверджувала перевертання традиції пригадування у вимірі différence/différance, одночасне нюансоване розрізнення „незапам'ятних” подій і суджень про них та постійне невдоволення ними й відсунення їх у майбутнє 3 відчуттям потреби до(за)повнити резервуар пізнання. Апорії як ознака кризової мнемонічної діяльності виявляли свою силу насамперед у сфері складного мортального мислення, що супроводжувалося філологічною грою, яка виключала можливість єдиної істини й передбачала іманентне безкінечне роз(по)двоєння, на зразок прощЕння/прощАння. У час деконструкційних філософувань Ф. Ніцше тріумф апорійності співвідносився із смертю Бога й людини та народженням надлюдини, яка вдавалася як до переоцінювання уявлень про Бога, так і до перенесення на себе його функцій. Саме так ні то свідомо, ні то несвідомо пише свої складні передсмертні послання прихильник Ніцше Хвильовий, що́ виявляють листи однієї адресатки: більше ніж через 55 років донька/падчерка не так запропонує їх розшифрування, скільки висуне під сумнів уже усталені в науці судження про батька-самовбивцю, мимоволі спрямувавши дослідників до атопічного оперування умовним дієслівним способом — маркером неможливо непростого простору.

\section{Бібліографія}

Arhìv Rozstrìlânogo Vìdrodžennâ: materìali arhìvno-slìdčih sprav ukraïns'kih pis'mennikìv 1920 1930-h rokiv, uporâd. O. j L. Uškalovih, Smoloskip, Kiïv 2010.

Avtonomova N., Filosofskij âzyk Žaka Derrida, Rossijskaâ političeskaâ ènciklopediâ (ROSSPÈN), Moskva 2011.

Dal' V., Tolkovyj slovar' živogo velikorusskogo âzyka: Sovremennoe napisanie. V četyrëh tomah, t. 3, AST Astrel', Moskva 2003.

Derrida J., Pardonner. Limpardonnable et l 'imprescriptible, Galileé, Paris 2012.

Derrida Ž., Dal'še mne predstoit idti odnomu, per. A. Melikân, https://www.gumer.info/bogoslov_ buks.

56 Л. Уманцева, „Він у крові”,.., с. 6.

57 Л. Новиченко, На позвах з істиною (Про деякі зарубіжні огляди української радянської літератури), „Вітчизна” 1959, № 12, с. 175-186. 
Derrida Ž., Dar smerti, per. Û. Azarovoj, „Vìsnik Harkìvs'kogo nacìonal'nogo unìversitetu ìm. V. N. Karazìna. Seriâ: teorìa kul'turi ì fillosofiâ nauki” 2, 2002.

Derrìda Ž., Daruvati čas, per. M. Ûŝenko, Lìtopis, L'vìv 2008.

Derrida Ž., Koncy čeloveka, [v:] idem, Polâ filosofii, per. D. Kralečkina, Akademičeskij Proekt, Moskva 2012.

Derrida Ž., O počtovoj otkrytke ot Sokrata do Frejda i ne tol'ko, per. G. Mihalkovič, Sovremennyj literator, Minsk 1999.

Derrìda Ž., Prividi Marksa, per. İ. Dončenko, red. O. Mamaluj, M. Rudenko, Oko, Harkìv 2000.

Derrida Ž., Vokrug Vavilonskih bašen, per. V. Lapickij, Akademičeskij proekt, Sankt-Peterburg 2002.

Derrida Ž., Rudinesko È., Iskat' svoe nasledie, per. N. Efremov, http://www.uhimik.ru/studia-humanitatis-symposium-ejegodnij-mejdisciplinarnij-jurna/index3.html.

Dnìprovs'kij İ., Zì ŝodennika 1933-go roku, „Ukraïns'kij zasìv” 1994, № 1.

Dorogij Arkadîu. Listuvannâ ta arhivariâ literaturnogo seredoviŝa Ukrä̈ni 1922-1945 rr., upor. L. Dems'ka-Budzulâk, Klasika, L'vìv 2001.

Grin A., Mertvaâ mat', per. E. Paškovoj, [v:] Francuzskaâ psihoanalitičeskaâ škola. Sbornik statej, red. A. Žibo, A. Rossohin, Piter, Sankt-Peterburg 2005.

Hvil'ovij M., Arabeski, [v:] idem, Tvori. U dvoh tomah, t. 1, uporâd. M. Žulins'kij, P. Majdačenko, Dnìpro, Kiïv 1990.

Hvil'ovij M., Peredsmertnì poslannâ do paserbicì Lûbovì Umancevoï ì do druzìv-pis'mennikìv, [v:] idem, Tvori. U dvoh tomah, t. 2, uporâd. M. Žulins'kij, P. Majdačenko, Dnìpro, Kiïv 1990.

Leonard L. Š., Èmocional'naâ ženskaâ travma: Iscelenie detskoj travmy, polučennoj dočer'û v otnošeniâh s otcom, per. V. Meršavki, Nezavisimaâ firma „Klass”, Moskva 2013.

List bez dati $\hat{U}$. Umancevoï. Fondi Harkìvs'kogo literaturnogo muzeû. Vst. № 304. RP4895/1-2.

List L. Umancevoï bez dati v Harkovi 02.12.93. Fondi Harkìvs'kogo literaturnogo muzeû. Vst. № 28788. РП 3959/1.

List L. Umancevoï bez dati. Fondi Harkìvs'kogo lìteraturnogo muzeû. NDF № 3203/2.

List L. Umancevoï vìd 03.05.94. Fondi Harkìvs'kogo lìteraturnogo muzeû. Vst. № 28786. RP 3958/2.

List L. Umancevoï vìd 16.05.90. Fondi Harkìvs'kogo lìteraturnogo muzeû. Vst. № 28737, RP 3929/1.

List L. Umancevoï vìd 21.03.91. Fondi Harkìvs'kogo lìteraturnogo muzeû. Vst. № 28741. RP 3933/1.

List L. Umancevoï vìd 22.03.1994. Fondi Harkìvs'kogo lìteraturnogo muzeû. Vst. № 28794. RP 3964.

List L. Umancevoï vìd 28.05.89. Fondi Harkìvs'kogo lìteraturnogo muzeû. Vst. № 28794. RP 3965/1.

List L. Umancevoï vìd 7.III.89. Fondi Harkìvs'kogo lìteraturnogo muzeû. Vst. № 28727. RP 3919/2.

List L. Umancevoï z nečitkoû datô̂ 1989. Fondi Harkìvs'kogo lìteraturnogo muzeû. Vst. 28745 RP $3937 / 1$.

Nicše F., Ecce homo. Kak stanovâtsâ sami soboj, per. Û. Antonovskij, [v:] idem, Sočineniâ. V dvuh tomah, t. 2, Mysl', Moskva 1990.

Novičenko L., Na pozvah z istinoû (Pro deâki zarubižnì oglâdi ukraïns'koï radâns'koï lìteraturi), „Vìtčizna” 1959, № 12.

O Dare: Diskussiâ meždu Žakom Derrida i Žanom-Lûkom Marimonom, per. V. Rokitânskogo, red. A. Âmpol'skoj, „Logos” 2011, № 3 (82).

Polûvannâ na „Val'dšnepa”. Rozsekrečenij Mikola Hvil'ovij. Naukovo-dokumental'ne vidannâ, uporâd. U.. Šapoval; peredm.: Û. Šapovala, V. Pančenka, Tempora, Kiïv 2009.

Rudinesko E., Fìlosofiv obijmah burì, per. O. Ûdìn, Nika-Centr, Kiïv 2007.

Rudinesko E., Navìso nam psihoanaliz?, per. Ê. Maričev, Nika-Centr, Kiïv 2008.

Skripnik M., Naša lìteraturna dijsnìst' (İz prikìncevogo slova na disputì v Harkovì v Budinku lìteratury ìm.. Blakitnogo 21 lûtogo 1928 r.), [v:] Šlâhi rozvitku ukraïns'koï proletars'koï lìteraturi. Literaturna diskusiâ (1925-1928). Zbirnik materiâlìv. Stattì, lìteraturnì manifesti, postanovi partiï v spravah hudožn'oï literaturi, uporâd. S. Fedčišin, red. V. Korâka, Ukraïns'kij robìtnik, Harkìv 1928.

Slavica Wratislaviensia 173, 2020

(C) for this edition by CNS 
Torok M., Bolezn' traura i fantazm čudesnogo trupa, per. A. Thostova, K. Kostarevoj, [v:] Francuzskaâ psihoanalitičeskâ̂ škola. Sbornik statej, red. A. Žibo, A. Rossohin, Piter, SanktPeterburg 2005.

Umanceva L., „Vìn u krovì mav: tvoriti, a zmušuvali viginatisâ...”. Besìda z dočkô̂ M. Hvil'ovogo O. Murzinoï, „Lenìns'ka zmìna” 16.09.1989.

Umanceva L., Učasnikam uročistogo zasidannâ, prisvâčenogo 100-rǐččù vìd dnâ narodžennâ Mikoli Hvil'ovogo, „Ukraïns'kij zasìv” 1994, № 1.

Velikij tlumačnij slovnik sučasnoï ukraïns'koï movi, red. V. Busel, İrpìn': VTF „Perun”, Kiïv 2003.

Zabužko O., Zamist' peredmovi: pam 'âtaûči pro Kamìros, [v:] eadem, „İ znov â vlizaû v tank...”. Vibanì teksti 2012-2016: Stattì, ese, interv ‘û, spogadi, Vid. dìm „Komora”, Kiïv 2016.

\section{The Difficulty of Bidding Farewell/Asking for Forgiveness: Mykola Khvylovyi’s Case}

\section{Summary}

The article attempts to use the philosophical deconstruction of Jacques Derrida's memory as a revolutionary renewal of the structure and meaning of farewell/forgiveness to analyse the case of Mykola Khvylovyi's. Khvylovy was a supporter of Friedrich Nietzsche, a "deconstructor before deconstruction" (Avtonomov). The relation of his works and the unpublished letters to Lubov Umantseva reveals many ways of the manifestation of life experience as an impossible farewell - an analogy of life after the father's death not only according to German überleben, fortleben, erleben, but also rethinking of thoughts, not only their repetition but also complication. Focusing on the emptiness and ruptures as the "wounds of truth", the author of this article analyses the paradoxes of the absence of a scene of forgiveness, as well as the lack of a farewell which, consequently, shattered the value of memories.

Keywords: deconstruction, farewell/forgiveness/excuse, gift, pardon, adieu

\section{Проблематичность проща(е)ния: случай Миколы Хвылевого}

Резюме

В статье предпринята попытка использовать предписания философской деконструкции памяти Жака Деррида как революционного обновления структуры и смысла прощания/прощения с целью критики предсмертных писем Миколы Хвылевого: писатель был сторонником Фридриха Ницше, которого считают „деконструктором до деконструкции” (Автономова). Реляция этих текстов и неизданных писем их адресатки Любови Уманцевой раскрывает множество способов проявления опыта пере-жизни как невозможного проща(е)ния - аналогии продолжения жизни после смерти отца не только в соответствии с немецкими überleben, fortleben, erleben, но и пере-мысливания его мыслей, то есть не только их повторения, но усложнения. Отсюда сосредоточение на пустотах и разрывах как „ранах истины”, анализ парадоксов отсутствия сцены прощЕния, с одной стороны, и прощАния, которого не было, с другой, расшатывающих ценность воспоминаний.

Ключевые слова: деконструкция, прощаться/прощать/извинять, дар, pardon, adieu

Slavica Wratislaviensia 173, 2020

(C) for this edition by CNS 